\title{
ARE FEMALES BETTER THAN MALES IN COMMUNICATION IN SECOND LANGUAGE?
}

\author{
IEVA RUDZINSKA \\ Ieva.Rudzinska@1spa.lv \\ Latvian Academy of Sport Education, Latvia
}

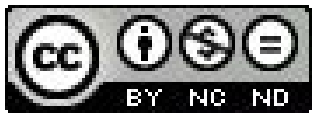

\begin{abstract}
Although research in education, including worldwide Programme for International Student Assessment (PISA) by the Organisation for Economic Co-operation and Development (OECD) and Progress in International Reading Literacy Study (PIRLS) by the International Association for the Evaluation of Educational Achievement, shows that female language learners outdo their male counterparts in the development of verbal skills, a number of researchers have strongly challenged that claim. The aim of this paper is to find out whether professional foreign language competence in a higher education institution (HEI) in Latvia is different between females and males. In order to determine this, we have analyzed final grades and presentation scores (lecturer, peer and self-assessment) of students in an ESP (English for Specific Purposes, in our case: Sport English) course, as well as their levels of second language acquisition, obtained in centralized secondary school leaving exams, which serves as the basis for further development of professional foreign language competence in a sport related HEI. Whereas grades, scores and levels are considered in the present paper as dependent variables, gender constitutes an independent variable. A series of Mann-Whitney $U$ tests has revealed no significant difference in male and female achievement in centralized school leaving exam in second language (English); in final grades, obtained by students in an ESP course; and in lecturer assessment of student presentations in the ESP course. However, the analysis of peer assessment of student presentations in the ESP course reveals that females tend to overestimate themselves and their peers. The latter observation, as this paper argues, may result from the fact that sport related HEI students are characterized by increased selfesteem (Rudzinska, 2007).
\end{abstract}

Key words: second language, English for specific purposes (ESP), gender differences in language learning, higher education.

\section{INTRODUCTION}

Research in education yields strong gender biased results in the development of verbal skills. Professional foreign language competence, which is developed in higher education in English for specific purposes (ESP) courses, is based on student verbal skills. It has been conclusively proved that women, regardless of age, possess better developed verbal skills than men. In Grade 1, girls seem to be better than boys at recognizing written words, inferring their meaning from context (Denton, \& West, 2002). It has also been found that 15 year old girls in all the countries participating in the Programme for International Student Assessment (PISA) by the Organisation for Economic Co-operation and Development (OECD) 2000 surpass their male equivalents in reading literacy, which is the ba- 
sis for communicative language competence and professional foreign language (Geske, \& Ozola, 2007). Results of the Progress in International Reading Literacy Study (PIRLS) by the International Association for the Evaluation of Educational Achievement 2001 show that the reading achievement, attitude to reading, as well as self assessment of reading among $4^{\text {th }}$ grade girls is significantly higher than that of $4^{\text {th }}$ grade boys (Johansone, 2003). Moreover, at advanced placement tests taken by highly selected high school students, women, on average, perform better in foreign language tests than men (Cole, 1997). Overall, women also dominate in accumulated knowledge, and especially with regard to verbal skills (The psychology of abilities, 2003).

Explanations for female verbal superiority have been sought in biological and in social factors, including stereotyping. Researchers have observed that women are better than men in, for instance, remembering lists of words or parts of texts; expressing empathy; developing interpersonal relations; and in emotional and artistic expression. All these aspects can result in female higher social and verbal skills (Koivula, 2001). Females adopt a learning style based on self-reflection, while the learning style of males could be described as spontaneous (Oxford, 1995). When learning a foreign language, males prefer activities that require them to use their logical and mathematical skills, while females favour activities that require intrapersonal intelligence (Loori, 2005).

Nonetheless, a number of researchers have put the conviction about verbal superiority of women under question (Mathuranath et al., 2003; Cameron, 2007). Many researchers have shown that the differences between men and women with respect to some abilities and skills (verbal skills, spatial capacity, mathematical way of thinking) constantly decrease, and even disappear (Zwick, 2002; Viskić-Štalec, \& Katović, 2001). Research into the development of professional foreign language competence in sport related higher education institutions HEIs has shown that women are not always superior when it comes to verbal skills (Omrčen, \& Bosnar, 2008a; Omrčen, \& Bosnar, 2010; Rudzinska, 2011).

Darija Omrčen and Ksenija Bosnar (Omrčen, \& Bosnar, 2010) offer to investigate the causes of bridging gender gap in verbal skills in sport related higher education institutions in closer look at respondents: students, interested in sports.

People who actively participate in physical activities develop a better perception of themselves (Sonstroem, 1997), which often leads to an increase of global self-concept (Spence, McGannon, \& Poon, 2005). Top-level athletes possess a higher level of emotional intelligence (Costarelli, \& Stamou, 2009). Differences in the development of verbal skills between athletes and non-athletes can be especially noticed in women, because by pursuing sport activities, they might not always have enough time for socializing and developing verbal skills (Omrčen, 2009). Verbal skills might improve also due to physiological factors. Louann Brizendine asserts that an increased amount of testosterone simultaneously diminishes interest in socializing, except for the cases of sports (and sex). Sport encourages communication, which, in turn, enhances verbal skills (Brizendine, 2008). 


\section{METHODS, RESEARCH INSTRUMENTS USED}

In order to prove/disapprove differences in male and female professional foreign language competence, we have compared three sets of scores, all of which characterize student foreign language competence.

\section{SUBJECTS}

Our participants (Grīnfelds, \& Geske, 2006) were Year One and Year Two Full time students from a HEI in Latvia, who studied ESP (Sports English) from study year 2008/2009 to study year 2011/2012. We have collected the following research material:

1. study outcomes in the form of student final grades in ESP course in two consecutive academic years. In 2008/2009, in the study involved 98 students (68 males and 30 females); in 2009/2010: 109 students (75 males and 34 females)

2. study outcomes in the form of student scores in presentation in the ESP course. The presentations have been assessed by lecturers, their peers and by the speakers themselves (altogether 110 students: 67 males, 43 females), the assessment is based on 5 criteria.

3. basis for the development of professional foreign language competence development in the form of the levels of second language acquisition, obtained in centralized secondary school leaving exams (345 students).

Scores, grades and levels were regarded as dependent variables, whereas gender constituted an independent variable.

For our study, we accepted only student final grades in ESP courses which were higher than 3 (on a scale from 1 to 10). Lower grades were not taken into consideration because they in most cases reflected the fact that the students had not attended the course. This fact however had no connection with students' level of professional foreign language competence.

Presentations were assessed on a scale from 1 to 6 and according to 5 presentation quality assessment criteria: language, content, structure, manner of speech and extra-linguistic factors. Total scores were obtained as mean values of lecturer, self and peer assessment scores.

Basis for the development of professional foreign language competence development is second language (English) learning in secondary education establishments, which is assessed in centralized secondary school leaving exams, using levels from $\mathrm{A}$ to $\mathrm{F}$ (altogether six levels, A being the highest and F the lowest level). Each level characterized the achievement on the exam in definite intervals of percentages. However in our research we did not use the whole interval of percentages, which characterizes all six levels. In order not to overcomplicate our research we used only the lower limits of percentages, corresponding to all six levels. Thus, for example, we used the lower limit for A level, which was $83.99 \%$, and the lower limit for $\mathrm{F}$ level, which was $31.99 \%$.

The normality of the distribution of the learning outcomes in the form of grades and scores, as well as the levels in centralized school leaving exams was in- 
vestigated by means of the Kolmogorov-Smirnov test; the significance and size of differences between the achievements in the development of professional foreign language competence in both genders was determined with the help of the Mann-Whitney $U$ test. The differences were regarded as being small, medium, or large according to Cohen. The probability value (p) of less than or equal to 0.05 was needed for the result to be significant.

\section{RESULTS}

The Kolmogorov-Smirnov test showed that the distribution of results deviated from normal one for all variables $(\mathrm{p} \leq 0.05)$; therefore, the Mann-Whitney $U$ test was used to identify any possible differences in achievement.

1. Study outcomes in the form of student final grades in ESP course

In study year 2008/2009, the Mann-Whitney U test revealed no significant difference in final Grades total in ESP course of males $(\mathrm{Md}=5.50)$ and females $(\mathrm{Md}=6.05), \mathrm{U}=788, \mathrm{z}=-1.81, \mathrm{p}=.07, \mathrm{r}=0.18$.

In study year 2009/2010 Mann-Whitney U test revealed no significant difference in final Grades total in ESP course of males $(\mathrm{Md}=6.00)$ and females $(\mathrm{Md}=$ 6.25), $U=1026, z=-1.65, p=0.10, r=0.16$.

2. Study outcomes in the form of scores in presentations

Presentation scores, obtained in self-assessment according to 5 scoring criteria (C1 to C5) are summarized in Table 1.

Table 1. Presentation scores obtained in self-assessment

\begin{tabular}{|c|c|c|c|c|c|c|}
\hline $\begin{array}{c}\text { Scoring } \\
\text { criteria }\end{array}$ & $\begin{array}{c}\text { Sum of } \\
\text { ranks (M) }\end{array}$ & $\begin{array}{c}\text { Sum of } \\
\text { ranks (F) }\end{array}$ & $\mathrm{U}$ & $\mathrm{z}$ & $\mathrm{p}$ & $\mathrm{r}$ \\
\hline C 1 & 3345.50 & 2759.50 & 1067.500 & -2.417 & 0.02 & -0.23 \\
\hline C 2 & 3272.00 & 2833.00 & 994.000 & -2.850 & 0.00 & -0.27 \\
\hline C 3 & 3013.50 & 3091.50 & 735.500 & -4.477 & 0.00 & -0.43 \\
\hline C 4 & 3156.50 & 2948.50 & 878.500 & -3.604 & 0.00 & -0.34 \\
\hline C 5 & 3133.00 & 2972.00 & 855.000 & -3.739 & 0.00 & -0.36 \\
\hline
\end{tabular}

Source: Author

Table 1 presents the results of Mann-Whitney U test. Regarding self-assessment according to criterion 3, for example, the sum of the ranks for male group students was found to be 3091.50, while the sum of the ranks for female group students was 3013.50. The observed difference is in favor of the ranks for female group students, or in other words, female self-assessment scores according to criterion 3 are statistically significantly higher than those of male group students. The last column of the table shows the difference ( $r$ values), $p$ values show the level of statistical significance.

Presentation scores obtained in peer-assessment are summarized in Table 2. 
Table 2. Presentation scores obtained in peer-assessment

\begin{tabular}{|c|c|c|c|c|c|c|}
\hline $\begin{array}{c}\text { Scoring } \\
\text { criteria }\end{array}$ & $\begin{array}{c}\text { Sum of } \\
\text { ranks (M) }\end{array}$ & $\begin{array}{c}\text { Sum of } \\
\text { ranks (F) }\end{array}$ & U & Z & p & $\mathrm{r}$ \\
\hline C 1 & 3117.50 & 2987.50 & 839.500 & -3.865 & 0.00 & -0.37 \\
\hline C 2 & 2921.00 & 3184.00 & 643.000 & -5.140 & 0.00 & -0.49 \\
\hline C 3 & 2909.50 & 3195.50 & 631.500 & -5.159 & 0.00 & -0.49 \\
\hline C 4 & 3110.50 & 2994.50 & 832.500 & -3.914 & 0.00 & -0.37 \\
\hline C 5 & 3047.50 & 3057.50 & 769.500 & -4.279 & 0.00 & -0.41 \\
\hline
\end{tabular}

Source: Author

Table 2 shows that there are statistically significant differences in presentation scores of males and females (female scores are higher), obtained in peer-assessment ( $\mathrm{r}$ values).

Presentation scores obtained in lecturer assessment are summarized in Table 3.

Table 3. Presentation scores obtained in lecturer assessment

\begin{tabular}{|c|c|c|c|c|c|}
\hline Variable & $\begin{array}{c}\text { Sum of } \\
\text { ranks (M) }\end{array}$ & $\begin{array}{c}\text { Sum of } \\
\text { ranks (F) }\end{array}$ & $\mathrm{U}$ & $\mathrm{z}$ & $\mathrm{p}$ \\
\hline C 1 & 3838.00 & 2267.00 & 1321.00 & -0.78 & 0.43 \\
\hline C 2 & 3681.50 & 2423.50 & 1403.50 & -0.24 & 0.81 \\
\hline C 3 & 3683.00 & 2422.00 & 1405.00 & -0.23 & 0.82 \\
\hline C 5 & 3716.00 & 2389.00 & 1438.00 & -0.02 & 0.99 \\
\hline
\end{tabular}

Source: Author

Table 3 shows that there are no statistically significant differences $(p>0.05)$ in presentation scores of males and females, obtained in lecturer assessment (no column with $r$ values).

\section{Total scores of student presentations}

Scores of student presentations (obtained as mean values of lecturer, self and peer assessment) according to Criterion 1 to Criterion 5 are summarized in Table 4 .

Table 4. Presentation Scores Total

\begin{tabular}{|c|c|c|c|c|c|c|c|c|}
\hline Criteria & $\begin{array}{c}\text { Median } \\
(\mathrm{M})\end{array}$ & $\begin{array}{c}\text { Median } \\
(\mathrm{F})\end{array}$ & $\begin{array}{c}\text { Sum of } \\
\text { ranks (M) }\end{array}$ & $\begin{array}{c}\text { Sum of } \\
\text { ranks (F) }\end{array}$ & $\mathrm{U}$ & $|\mathrm{z}|$ & $\mathrm{p}$ & $|\mathrm{R}|$ \\
\hline C 1 & 4.00 & 5.00 & 3254.00 & 2851.00 & 976.00 & 3.03 & 0.00 & 0.29 \\
\hline C 2 & 5.00 & 5.00 & 2926.00 & 3179.00 & 648.00 & 5.26 & 0.00 & 0.50 \\
\hline C 3 & 4.00 & 5.00 & 3129.00 & 2976.00 & 851.00 & 3.84 & 0.00 & 0.37 \\
\hline C 4 & 4.00 & 4.00 & 3354.50 & 2750.50 & 1076.50 & 2.43 & 0.02 & 0.23 \\
\hline C 5 & 4.00 & 5.00 & 3107.50 & 2997.50 & 829.500 & 3.98 & 0.00 & 0.38 \\
\hline
\end{tabular}

Source: Author 
Table 4 shows that there are statistically significant differences in presentation Scores Total of males and females ( $\mathrm{r}$ values).

Finally were calculated Grand Total Scores in presentations as mean value of all 5 criteria. Grand Total Scores in presentations were analyzed with the help of Mann-Whitney U test, which revealed no significant difference in presentation scores of males $(\mathrm{Md}=4.00)$ and females $(\mathrm{Md}=5.00), \mathrm{U}=893, \mathrm{z}=-3.67$, $\mathrm{p}=.00, \mathrm{r}=-0.35$.

3. The Mann-Whitney $U$ test revealed no significant difference in centralized secondary school leaving exam levels of males $(n=209)$ and females $(n=136)$, $\mathrm{z}=-0.60, \mathrm{p}=0.55, \mathrm{r}=0.03$.

\section{CONCLUSIONS}

Our research has revealed no significant difference in male and female achievement in centralized school leaving exam in second language (English); in final grades, obtained by students in an ESP course; and in lecturer assessment of student presentations in the ESP course. However, the analysis of self-assessment and peer assessment of student presentations in the course reveals that females tend to overestimate themselves and their peers.

Based on the results of our experimental data, it can be assumed that the verbal skills of young males engaging in sport activities are not inferior to those of females. It is already upon entering a HEI that the foreign language skills of both gender groups are equally high. The conclusion can thus be drawn that the study process at higher education institutions has not changed this proportion; it has been equally challenging for both genders and has not favored female students over male students, which is the case in many other formal language learning environments.

The basis for bridging the gender gap in verbal skills might be physiological (increased level of testosterone, which combined with engaging in sport activities, increases interest in communication), psychological (increased self-esteem and emotional intelligence) and social (participating in international camps and competitions).

The finding that the participants of our study over evaluate their and their female peer student achievement in presentations might result from their increased self-esteem, which is especially typical of students who attend sport related higher education institutions (Rudzinska, 2007).

Another observation made on the basis of our research might be that sports promotes the formation of a more harmonious personality, brings males closer to females, and vice versa. The question remains, however, whether we want gender differences to disappear or not.

\section{REFERENCES}

Brizendine, L. (2008). Ženski mozak [Female brain], Zagreb: Profil, pp. 63, 68.

Cameron, D. (2007). Unanswered questions and unquestioned assumptions in the study of language and gender. Female verbal superiority, Gender and Language, 1. 15-25. 
Cole, N. (1997). The ETS Gender Study: How Females and Males Perform in Educational Settings, Princeton, N.J.: Educational Testing Service.

Denton, K., \& West, J. Children's Reading and Mathematics Achievement in Kindergarten and First Grade, Washington DC: National Center for Education Statistics, 2002.

Geske, A., \& Ozola, A. (2007). Skolènu sasniegumi lasìtprasmē Latvijā un pasaulē [Student achievement in reading literacy in Latvia and the world], Rīga: LU Akadēmiskais apgāds.

Geske, A., \& Grīnfelds, A. (2006). Izglìtïbas pētnieciba: mācỉbu grāmata augstskolu izglìtïbas un pedagoóijas profesionālo un akadēmisko studiju programmu studentiem, [Research in education: textbook for higher education institution education and pedagogy professional and academic program students], Rīga: LU Akadēmiskais apgāds.

Johansone, I. (2003). Starptautiskais lasitprasmes novērtēšanas pētījums 2000-2003 [International PIRLS investigation 2000-2003], Rīga: Mācību grāmata.

Koivula, N. (2001). Perceived characteristics of sports categorized as gender-neutral, feminine and masculine, Journal of Sport Behaviour, 24. 377-393.

Loori, A.A. (2005). Multiple intelligences: a comparative study between the preferences of males and females, Journal of Social Behaviour and Personality, 33. 77-88.

Mathuranath, P. S. et al. (2003). Effects of age, education and gender on verbal fluency, Journal of Clinical and Experimental Neuropsychology, 25, 1057-1064.

Omrčen, D. \& Bosnar, K. (2010). Gender Stereotyping Bias - Assessment of the Swimming and Underwater Diving Vocabulary Knowledge in English as a Foreign Language in Kinesiology", In S. Orthaber, \& P. Vičić (Eds.) Proceedings CD of the international language conference "The importance of learning professional foreign languages for communication between cultures", University of Maribor, Faculty of Logistics: Celje, Slovenia.

Oxford, R. (1995). Gender differences in language learning styles: What do they mean?, In J.M. Reid (ed.), Learning styles in the EFL/ESL classroom, (pp. 34-46). Newbury House: Heinle \& Heinle,

Rudzinska, I. (2011). Bridging the gender gap in student professional foreign language competence, In S. Orthaber and P. Vičić (Eds.) Proceedings CD of the international language conference "The importance of learning professional foreign languages for communication between cultures", University of Maribor, Faculty of Logistics: Celje, Slovenia.

Rudzinska, I., (2007). Problems of Preparedness for Taking Tests and Self-Assessment, Based on The Example of Sports English Study Course, Polish Journal of Applied Psychology, 5 (1), 113-122.

Sonstroem, R.J., (1997). The physical self-esteem: A mediator of exercise and self-esteem, In K.R., Fox (Ed.), The physical self: From motivation to well being. Champaign, pp. 3-26, IL: Human Kinetics.

Spence, J.C., McGannon, K.R., Poon, P. (2005). The effect of exercise on global self-esteem: A quantitative review, International Journal of Sport and Exercise Psychology, 27, 311-334.

Sternberg, R.J., Grigorenko, E.L. (ed.) (2003). The psychology of abilities, competencies and expertise, Cambridge: Cambridge University Press.

Viskić-Štalec, N., \& Katović, D. (2001) Skydive virtual environment: cognitive processing, In Hughes, M, \& Franks, I. M. (eds.), Pass.com performance analysis, Sport Science, Computers (pp. 49-56). Cardiff : Centre for Performance Analysis, UWIC.

Zwick, R. (2002) Fair game? The use of standardized tests in higher education, New York: Routledge Falmer. 